\title{
SOCS2 expression in bone marrow derived dendritic cells is a positive regulator of T cell activation
}

Jin $\mathrm{Hu}^{1 *}$, Berit Carow ${ }^{4}$, Ann-Charlotte Wikström ${ }^{3}$, Martin Rottenberg ${ }^{4}$, Gunnar Norstedt $^{2}$, Ola Winqvist ${ }^{1}$

From 7th European Workshop on Immune-Mediated Inflammatory Diseases

Noordwijk aan Zee, the Netherlands. 28-30 November 2012

\section{Background}

After a completed $\mathrm{T}$ cell response the activation of DCs needs to be terminated to avoid harmful inflammation or autoimmune disease. Besides the negative regulation of
JAK/STAT signaling pathway on growth hormone and prolactin for suppressor of cytokine signaling (SOCS) 2 [1], murine SOCS2-/- DCs are recently found to be hyperresponsive to microbial stimuli and refractory to the inhi-

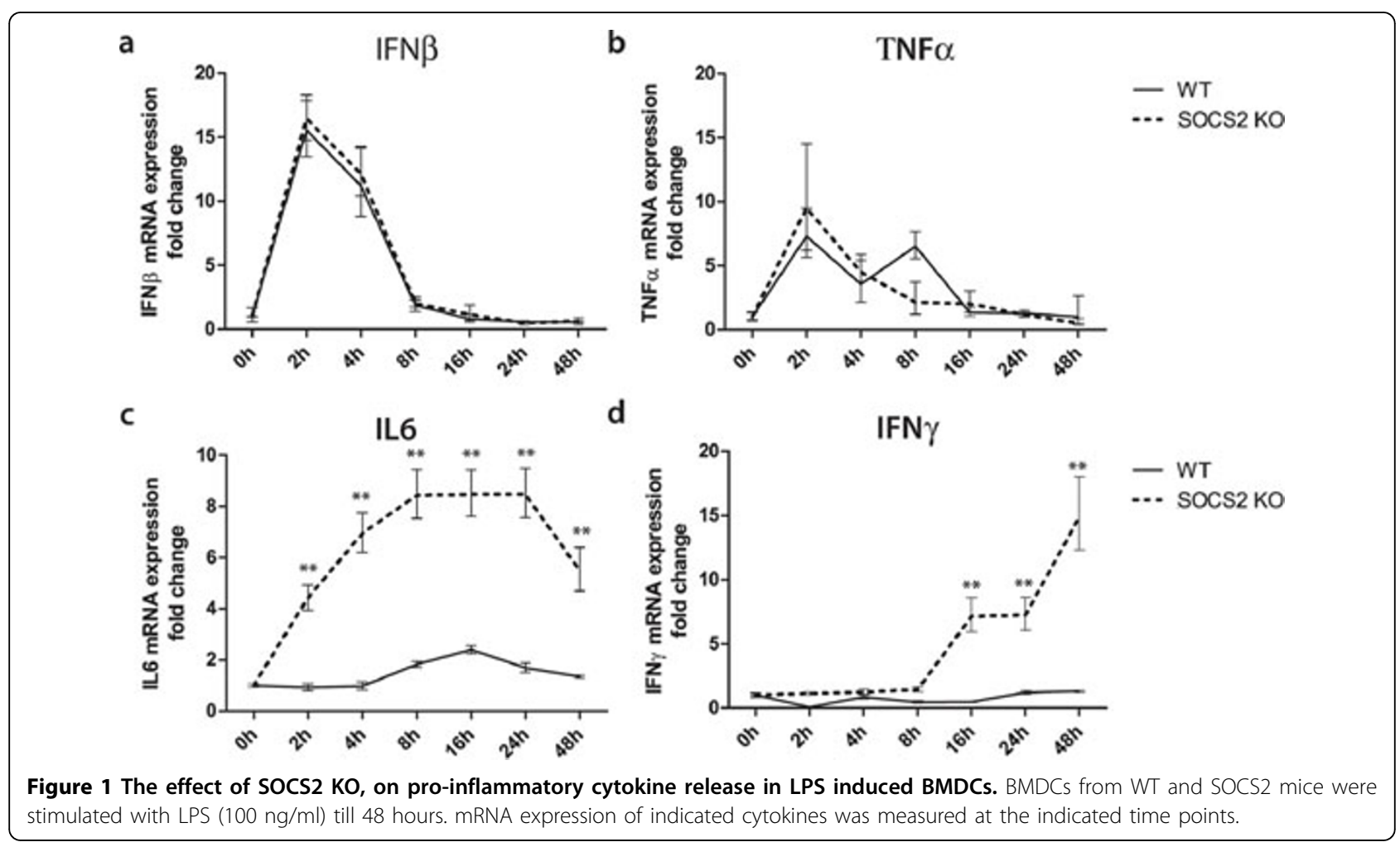

'Dept. of Medicine, Translational Immunology Unit, Karolinska Institutet,

Stockholm, Sweden

Full list of author information is available at the end of the article 


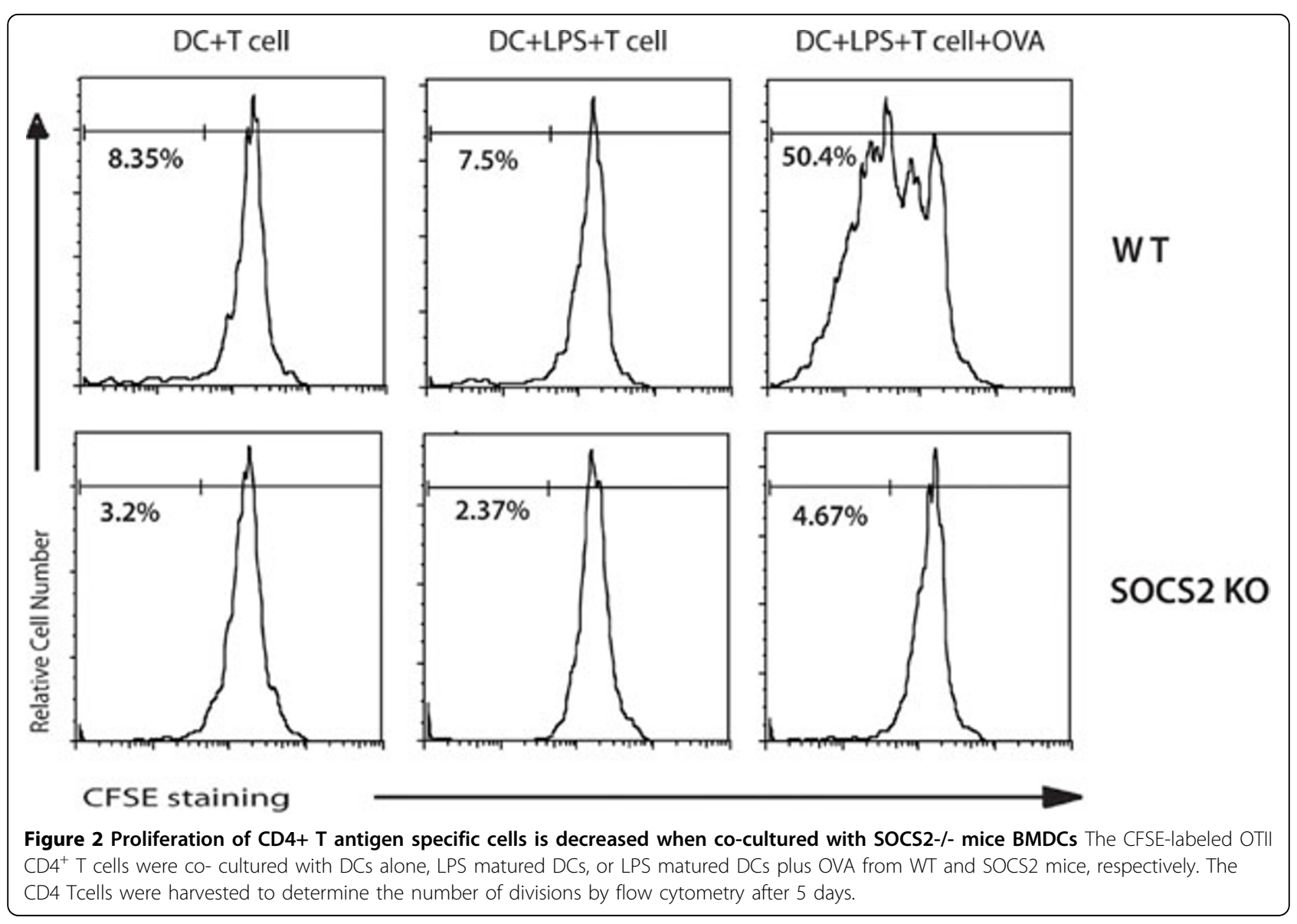

bitory actions of the anti-inflammatory mediator LXA4 [2]. Thus, we investigate the role of SOCS2 in DC antigen presentation.

\section{Materials and methods}

Mice: SOCS2 deficient mice and transgenic OT-II mice. Mouse bone marrow-derived dendritic cells (BMDCs): Mouse bone marrow cells were incubated 7 days with $20 \mathrm{ng} / \mathrm{ml} \mathrm{GM}-\mathrm{CSF}$ and $20 \mathrm{ng} / \mathrm{ml} \mathrm{IL-4}$ to create mouse BMDCs. Quantitative RT-PCR: Real-time PCR was used to measure pro-inflamatory cytokines gene expression. CFSE proliferation assay: BMDCs were incubated with $100 \mathrm{ng} / \mathrm{ml}$ LPS and $50 \mathrm{ng} / \mathrm{ml}$ OVA323-339 peptide. The next day CD90+ splenocytes from OT-II mice were labeled with CFSE and added to the BMDC culture for 5 days. Then cells were stained for CD4 and read by FACS.

\section{Results}

Increased production of pro-inflammatory cytokines by $S O C S 2^{-/-}$BMDCs in response to LPS (see Figure 1)

$\mathrm{SOCS}^{-1-}$ BMDCs have a decreased capacity to activate naïve $C D 4^{+} T$ cells (see Figure 2)

\section{Conclusions}

SOCS2 is complex regulator of DC effecter functionality, with an overall positive regulatory function on $\mathrm{T}$ cell activation.

\section{Author details}

'Dept. of Medicine, Translational Immunology Unit, Karolinska Institutet, Stockholm, Sweden. ${ }^{2}$ Dept. of Molecular Medicine and Surgery, Karolinska Institutet, Stockholm, Sweden. ${ }^{3}$ Dept. of Biosciences and Nutrition, Karolinska Institutet, Stockholm, Sweden. ${ }^{4}$ Dept. of Microbiology, Tumor and Cell Biology, Karolinska Institutet, Stockholm, Sweden.

Published: 28 November 2012

\section{References}

1. Rico-Bautista E, Flores-Morales A, Fernandez-Perez L: Suppressor of cytokine signaling (SOCS) 2, a protein with multiple functions. Cytokine Growth Factor Rev 2006, 17:431-439.

2. Machado FS, Johndrow JE, Esper L, Dias A, Bafica A, et al: Antiinflammatory actions of lipoxin $A 4$ and aspirin-triggered lipoxin are SOCS-2 dependent. Nat Med 2006, 12:330-334.

doi:10.1186/1479-5876-10-S3-P19

Cite this article as: Hu et al:: SOCS2 expression in bone marrow derived dendritic cells is a positive regulator of T cell activation. Journal of Translational Medicine 2012 10(Suppl 3):P19. 